\title{
Design and Development of Agricultural Spraying Drone: Spraying System and Tank
}

\author{
Shantanu D. Munghate ${ }^{1} \mid$ Dr. Prashant S. Kadu ${ }^{1}$ \\ ${ }^{1}$ Department of Mechanical Engineering, AGPCE Nagpur, Nagpur, Maharashtra, India
}

To Cite this Article

Shantanu D. Munghate and Dr. Prashant S. Kadu, "Design and Development of Agricultural Spraying Drone: Spraying System and Tank", International Journal for Modern Trends in Science and Technology, 6(8): 221-232, 2020.

\section{Article Info}

Received on 19-July-2020, Revised on 04-August-2020, Accepted on 10-August-2020, Published on 18-August-2020.

\section{ABSTRACT}

Designing the drone for spraying has become one of the essential concerns in recent developments in technology in order to avoid human involvement in the spraying phenomenon. While designing the spraying drone it is important to design the components according to according to specifications. In this paper a tank carrying a spraying liquid of 3 lt. for spraying herbicide over rice crop. This paper deals with the selection of spraying liquid and spraying system required for the spraying operation. The spraying system includes the pump, nozzle and carrying media(pipes). The spraying tank is analyzed for drag and lift at different angles of the front face is titled at different angles between 0 to $60^{\circ}$ with the vertical. The optimum tank configuration has been selected for the design. The paper also includes selection of herbicide, pump and nozzles for the drone spraying assembly.

KEYWORDS: UAV, Drone, spraying, nozzle, herbicide

\section{INTRODUCTION}

Designing a spraying drone includes design of several components including the frame and spraying assembly along with selection of components such as motors, propellers and electronics component. This paper is the second paper in the series of design and development of agricultural spraying drone and it deals with the design of tank and selection of spraying system.

The paper includes selection of liquid to be sprayed and according to the amount and speed required the selection of nozzle is done. As per the requirement of nozzle, pump has been selected. After the selection of pump, a tank with the volume of 3 lt. is designed using Computational Fluid Dynamics by analyzing its drag and lift capabilities under front face angle ranging between 0 to $60^{\circ}$.After analyzing the tank, a control equation is proposed for the controller.

\section{LITERATURE REVIEW}

Wen, s. et al (2019) [1]The author made an attempt to analyze the drift and movement of droplets with respect to flight speed and altitude of a quadrotor UAV. The quadrotor flying at $2 \mathrm{~m} / \mathrm{s}$ with boom height of 0.25 , nozzle spacing of $0.4 \mathrm{~m}$ at $1 \mathrm{~m}$ height. The pressure used is $1 \mathrm{MPa}$ with the flow rate of $4 \mathrm{~L} / \mathrm{min}$ and the spray angle of $110^{\circ}$ and the fluid medium density $998.2 \mathrm{~kg} / \mathrm{m} 3$ and viscosity of 1.004E-03 Pa-s. The author used 0.3, 0.4 and $0.5 \mathrm{~m}$ as the distance between the nozzles to find out effective nozzle position. The author found out $0.4 \mathrm{~m}$ to be the appropriate distance in order to reduce the drift. According to the author the nozzle spacing and position have a very less effect rather the altitude and flight speed caused a horseshoe shaped eddy current in the downwash. This resulted into entrainment and uneven deposition with drift of droplet. There is 
stimulation of $1-2 \mathrm{~m}$ of flight altitudes and $1-7 \mathrm{~m} / \mathrm{s}$ of flight speeds of quad-rotor drone. $5 \mathrm{~m} / \mathrm{s}$ is an exceeding speed where horseshoe-shaped vortices were successfully captured. The capacity of medical kit tank of drone is 10L. The test wind speed used in the experiment was $0.4 \mathrm{~m} / \mathrm{s}$.

Yallappa D. et al(2017) [2] The drone mounted sprayer was used for groundnut and paddy crop with the field efficiency of $62.84 \%$ and $60.00 \%$. The spray application was evaluated for the field capacity of $1.15 \mathrm{ha} / \mathrm{h}$ and $1.08 \mathrm{ha} / \mathrm{h}$. Four nozzles were fixed on a length of $1.3 \mathrm{~m}$ boom with a nozzle spacing of $45 \mathrm{~cm}$ along with a $12 \mathrm{~V} \mathrm{DC}$ pump. The developed drone was able to carry 5.5 liters for about 16 minutes. It was found that, the VMD and NMD of spray droplet size for the height of $1 \mathrm{~m}$ and a speed of $3.6 \mathrm{kmph}$ were 345 and $270 \mu \mathrm{m}$.

Meivel, S. et al (2016) [3] The author used a spraying system with $11 / \mathrm{min}$ discharge rate with a spraying height of $4 \mathrm{~m}$ and speed of $5 \mathrm{~m} / \mathrm{s}$ for a range of $2 \mathrm{~m}$. The author obtained coverage rate of $3.5 \mathrm{acre} / \mathrm{hr}$ and $7 \mathrm{acre} / \mathrm{hr}$ for the speed of $2 \mathrm{~m} / \mathrm{s}$ and $4 \mathrm{~m} / \mathrm{s}$.

Y. Huang et al (2009) [4] The author employs Rotomotion's SR200 VTOL Helicopter for the purpose of low volume spraying. It has rotor diameter of $3 \mathrm{~m}$ and payload capacity of $22.7 \mathrm{~kg}$ while it was used to cover 14 ha with $0.1 /$ ha low volume sprayer. The spray swath width of $30 \mathrm{~m}$ with $2.2 \mathrm{~m} / \mathrm{s}$ air speed and $100 \mathrm{ml} / \mathrm{min}$ rate. The droplet size of $<50 \mu \mathrm{m}$ was obtained using the vector control. The author designed a spraying system for low volume sprayer. The author used a 6061 aluminium sheet tank of $1.5 \mathrm{~mm}$ thickness with a size of $11.4 \times 17.8 \times 25.4 \mathrm{~cm}$. The tank carried $5 \mathrm{~kg}$ payload weight while the tank weighed $1 \mathrm{~kg}$.

Vihari, M. M.,et al(2018) [5] In this paper an IoT based drone is designed by the author for the agricultural applications. The author has used a KK 2.1.5 flight controller. The spray time as well as the endurance time was 6 to 7 minutes with coverage of 50 sq. $m$ and achieved the height of $6 \mathrm{ft}$. The spray tank was $250 \mathrm{ml}$ with the nozzles inserted in it.

Karan Kumar Shaw et al (2020) [6] In this paper an Octacopter was selected for the design for spraying with a tank $(200 \times 300 \times 110 \mathrm{~mm})$ filled with liquid and 6 liters storage capacity including the $12 \mathrm{~V}$ pump and 4 nozzles. the nozzles at a distance of $45 \mathrm{~cm}$ from each other.

Xuan Li et al [7] The author laid out some Best Management Practices for the insecticide application of UAV. The following recommendations were made by the author: 1 . Avoid rain or overhead irrigation and spray at least two hours before to allow absorption. 2 . Recommended wind speed is between 1.5 to $3 \mathrm{~m} / \mathrm{s}$ in order to avoid drift. 3. Maintaining droplet size in case of low wind speed in order to ensure proper canopy penetration. 4. Avoiding temperature inversion. 5. Spray height between 1.5 to $3 \mathrm{~m}$. 6 . Spraying speed of 3 to $6 \mathrm{~m} / \mathrm{s}$.

Aleksandra Pachuta et al (2018) [8] In this paper author used DGTJ60-11002 twin flat nozzle for spraying using a drone. Test were conducted at different liquid pressures viz. 0.2, 0.3 and 0.4 MPa. The author attempted to find out the effect of airstream on liquid volume deposed. The author found out that the shape change was caused by air stream produced by drone rotors which was found to be asymmetric with respect to nozzle axis.

Boguslawa Berner et al (2018) [9] The author used Teejet XR11001 on a drone to find out distribution of deposited liquid with respect to individual parts of plants from plant height and air flow. The liquid pressure was 0.2 MPa while it was used to spray over crop height between 0.9 to $1 \mathrm{~m}$ above soil surface. The effect of plant height and rotors work on liquid deposition was found to be with a significance level of less than 0.05. The air stream from the rotors had positively improved the uniformity of settling of the liquid on the plants

Anken Thomas et al (2020) [10] In this paper author examined to UAV for the purpose of spraying of fertilizers and pesticides in crop field. Author developed two homologation method to analyze the spraying accuracy and possible spray drift. The two drones used are Huanaco AG-V6A which is hexacopter with engine TTA1030 and Agras DJI MG-1 which is octacopter with engine DJI6010. Weight of Huanaco is $37.5 \mathrm{~kg}$ with tank capacity of $15.2 \mathrm{Lt}$ and 4 spraying nozzle and weight of Agras is $24.1 \mathrm{~kg}$ with tank capacity of 10 Lt and 4 spraying nozzles. Author stated that modified patternator is good method to study the precision of spraying of drones and also used to measure the regularity of distribution

Yayong Chen et al (2019) [11] Nozzle and Tank: In this paper author used quadcopter ZHKU-0404-01 which contains wind sensors viz QS-FSO1 and QS-FX01, spraying parts and Arduino (MEGA 2560-R3) is used as controller, water pump Qp-2203, steering material MG995 and spraying nozzle VP110-015. Wind speed during flight ranges from 0 to $5.92 \mathrm{~m} / \mathrm{s}$. This drone can carry $27 \mathrm{Kg}$ payload and has a 10 flight time/min. To lower the spraying drift new method of adjusting spraying 
angle and spraying pressure for protection of plant is studied.

Weicai Qin et al [12]The spraying was done with $0^{\circ}$ angle with vertical with two nozzles (rotary atomizer) spaced at Small UAV N3 and its spraying parameters with respect to different height and concentration are the key factors of the investigation conducted by this paper. The working height was 3.5 to $5 \mathrm{~m}$ with the flying speed of 4 $\mathrm{m} / \mathrm{s}$. For the height of $5 \mathrm{~m}$ and speed of $4 \mathrm{~m} / \mathrm{s}$ the coverage rate was found to be the highest at the lowest layer of wheat crop.

S.Meivel M.E. et al (2016) [13] Two section of sprayer module are Transmitter (Remote Controller) Section and Sprayer with Controller. Actuator of the sprayer module is controlled by the Transmitter Section too it activates the nozzle sprayer. The nozzle of the sprayer can be activated by the GPS device too.

Matsuura, F. et al (2017) [14] In this paper author used octacopter for spraying in farm fields, this octacopter contains aluminium frame and commercial spraying system. Drone has 2L tank capacity with spraying capacity of 470-480 $\mathrm{ml} / \mathrm{min}$, spraying device DJI S1000 is used here. Author performed comparison experiments with changing the nozzles position and changing rotation speed. Wind speed were changed to $400 \mathrm{~mm}$ under the rotor to $0,10,14,18 \mathrm{~m} / \mathrm{s}$.

Tejas S. Kabra et al (2017) [15] Author used 1.5 1t. to 3 lt.tank for storing pesticides in farm field. Tank has lightweight plastic body. Tank is removable and washable. Author give slant at the bottom of the tank to upgrade gravity stream. . Maximum Velocity of quadcopter is $0.7 \mathrm{~m} / \mathrm{s}$ and maximum time of spraying is $23.5 \mathrm{sec}$. Actual velocity of quadcopter is $0.62 \mathrm{~m} / \mathrm{s}$ and time of spraying $13.975 \mathrm{sec}$.

Tang, $Y$ et al (2018) [16] The author is investigating effect of operating height and tree shape on the droplet deposition over citrus plants. The author used a quadcopter (ZHKU-0404-01) with the flight speed of $1.5 \mathrm{~m} / \mathrm{s}$. The spraying system includes a tank of $15 \mathrm{~L}$ with $2-4$ nozzles (flat fan) distributed over a boom length of $2.2 \mathrm{~m}$. The spraying operation accomplished with the pressure of 0.2-1.0 $\mathrm{MPa}$ while the flow rate of $3.5 \mathrm{~L} / \mathrm{min}$. Authors investigation lead to the results which included the optimum height of spraying as $1.2 \mathrm{~m}$ with the speed of $3.5 \mathrm{~m} / \mathrm{s}$. over the tree height of $2.4 \mathrm{~m}$ (approximately). While investigating the effect of operation height and tree shape the author used UAV with four rotors (ZHKU-0404-01).
Qin, W.et al (2018) [17] This paper deals with the UAV(UAV N-3) that deals with the studies of spraying parameters which leads to powdery mildew prevention too shows the deposition of droplets on the wheat canopy. The spraying speed was $4 \mathrm{~m} / \mathrm{s}$ with height of $5.0 \mathrm{~m} / \mathrm{s}$. Author used single rotor $(\Phi 3.2 \mathrm{~m})$, and the used nozzle type is Rotary atomizer. The speed nozzle numbers are 2 whereas driving speed is $4 \mathrm{~m} \cdot \mathrm{s}-1$ with $15 \mathrm{~L} \cdot \mathrm{hm}-2$ as a spraying volume. $5 \mathrm{~L}$ is the tank capacity; low volume and high concentration will be the spraying pattern.

Joseph E. Hunter et al ( April 2020) [18] Here author presents the UAV Technology for the application of pesticides by using sprayers. Speed of Application for $1 \mathrm{~m} / \mathrm{s}$ ranged from $30 \%$ to $60 \%$ meanwhile for $7 \mathrm{~m} / \mathrm{s}$ it would be $13 \%$ to $22 \%$ of the coverage area. hence, due to higher drift the application of speed of the nozzles is inversely proportional to the coverage area. As per the conduced experiments in the absence of natural winds at the height of $1.75 \mathrm{~m}$ above by keeping perpendicularly we may conduct the it by using different types of nozzles.

Saddam Hussain et al (2019) [19] In this paper author is using a Hexacopter UAS for pesticides spraying. Four Different Heights ranging from 1.5 to $3 \mathrm{~m}$ were used with different nozzle opening $(25-100 \%)$ at variable speed ranging from $1 \mathrm{~m} / \mathrm{s}$ to $5.8 \mathrm{~m} / \mathrm{s}$ under wind speeds between $1 \mathrm{~m} / \mathrm{s}$ to 5.8 $\mathrm{m} / \mathrm{s}$. Author obtained uniform coverage at $1.5 \mathrm{~m}$, nozzle openings $(50,75$ and $100 \%), 1 \mathrm{~m} / \mathrm{s}$ speed and different wind speeds. The tank capacity used was of $15 \mathrm{~L}$ capacity with the total take-off capacity of $38 \mathrm{~kg}$ for the flight time of 15 minutes. This paper is dealing with a spraying using Hexacopter UAAS system. Two flat fan nozzles were used over a span of $4 \mathrm{~m}$. These nozzles were used with the nozzle opening between 25 to $100 \%$. The Hexacopter was operated between the speed of 0-6 $\mathrm{m} / \mathrm{s}$ for spraying the pesticides of $15 \mathrm{~L}$. The operational nozzle angle was $6^{\circ}$.

\section{SELECCTION OF HERBICIDE}

The average wind speed value in Nagpur region for January 2014 to December 2019 as estimated by weatheronline.in is $6.3 \mathrm{~km} / \mathrm{h}$ which is equal to $1.75 \mathrm{~m} / \mathrm{s}$. [20] This wind speed is usually categorized into light breeze category and considered ideal for spraying. [21] Mean spray coverage was significantly $(\mathrm{p}<0.05)$ higher at a travel speed of $29 \mathrm{~km} / \mathrm{h}(18 \mathrm{mph})$ with a very coarse droplet size. Based on these results, it is recommended that applicators pair larger droplet 
sizes with higher speeds when applying contact herbicide in a burndown situation. Droplet sizes are categories are classified a Fine(F), Medium (M), Coarse (C), Very coarse (VC), Extra Coarse (XC) and Ultra-Coarse (UC). The Two categories are spray liquid are important in selecting the droplet size, contact and systemic. Contacts rely on thorough coverage of the plant material (smaller droplet) while Systemics also need good coverage and rely on concentration of the solution (larger droplet) too.

According to the ICAR information bulletin on 'Herbicide use in Indian Agriculture' Maharashtra is one of the largest consumers of herbicides. One most common herbicide used by the rice growing states include pretilachlor $50 \%$ EC. The overall consumption in 2007 is about 2122.50 tones. [22] The bio-efficiency, economics and microbial study conducted by Dibyendu Mondal recommends $600 \mathrm{~g} / \mathrm{ha}$ use of Pretilachlor 50\% EC for higher yield. [23] In the eastern Vidarbha region the common method of rice cultivation is puddle transplanted method. Also, the weed flora found in the rice crop Echinocloa crus-galli and Echinochloa colonum can be treated using Pretilachlor 50\% EC. [24] [25] The overall expenditure of state of Maharashtra in 2007 on Pretilachlor $50 \mathrm{EC}$ for 108.67 tonnes is Rs.34.80 crores. [22] According to Ministry of Agriculture and Farmers Welfare, Government of India in the approved uses of herbicides Pretilachlor 50\% EC following recommendations have been made:

Table 3.1 Recommended uses of Pretilachlor 50\% EC

\begin{tabular}{|c|c|c|c|c|c|}
\hline $\begin{array}{l}\text { Herbici } \\
\text { de } \\
\text { Name }\end{array}$ & $\begin{array}{l}\text { Approve } \\
\text { d Crops }\end{array}$ & \multicolumn{2}{|c|}{ Dosage/ha } & $\begin{array}{l}\text { Dilut } \\
\text { ion }\end{array}$ & $\begin{array}{l}\text { Wait } \\
\text { ing } \\
\text { time }\end{array}$ \\
\hline \multirow[t]{2}{*}{$\begin{array}{l}\text { Pretila } \\
\text { chlor } \\
50 \% \\
\text { EC } \\
\text { (syste } \\
\text { mic) }\end{array}$} & \multirow[t]{2}{*}{$\begin{array}{l}\text { Transpl } \\
\text { anted } \\
\text { Rice }\end{array}$} & $\begin{array}{l}\text { a.i. } \\
\text { (gm/ } \\
\text { Kg) }\end{array}$ & $\begin{array}{l}\text { Formul } \\
\text { ation in } \\
\text { (gm/ } \\
\mathrm{ml} \\
\text { / Kg/ } \\
\text { ltr) }\end{array}$ & $\begin{array}{l}\text { In } \\
\text { Wate } \\
\text { r per } \\
\text { (lt) }\end{array}$ & $\begin{array}{l}\text { (day } \\
\text { s) }\end{array}$ \\
\hline & & $\begin{array}{l}0.50- \\
0.75 \\
\mathrm{~kg} .\end{array}$ & $\begin{array}{l}1.0-1.5 \\
\text { ltrs. }\end{array}$ & $\begin{array}{l}500- \\
700\end{array}$ & $\begin{array}{l}75-9 \\
0\end{array}$ \\
\hline $\begin{array}{l}\text { Weed } \\
\text { species }\end{array}$ & \multicolumn{5}{|c|}{$\begin{array}{l}\text { Echinochloa crusgalli, Echiniochloa } \\
\text { colonum, Cyperus difformis, Cyperus iria, } \\
\text { Fimbristylis miliacae, Eclipta alba, } \\
\text { Ludwigia parviflora,Monochoria vaginalis, } \\
\text { Leptochloa chinensis, Panicum repens }\end{array}$} \\
\hline
\end{tabular}

\section{NOZZLE SELECTION}

Meiqaio Lv has analyzed the influence of flight speed on droplet deposition. The analysis concluded that deposition density and coverage, mean droplet size decreases with increasing speed. [26] A. S. Mat Su in his study suggests that height of 1.5 to $2.0 \mathrm{~m}$ from the crop is suitable for spraying over rice crop. [27]

In order to avoid spray drift following factors should be considered: droplet size, spray height, operating speed, wind velocity, air temperature and humidity and crop protection chemicals and volume. Considering all these factors following selection procedure is adopted.

$1 / \mathrm{min}$ required per nozzle $=\frac{\mathrm{l} / \mathrm{ha} \times \mathrm{km} / \mathrm{h} \times \mathrm{W}}{60,000}$

where, $1 / \mathrm{min}$ - liters Per Minute, 1/ha - liters Per Hectare, $\mathrm{km} / \mathrm{h}$ - Kilometers Per Hour, W - Nozzle spacing (in $\mathrm{cm}$ ) for broadcast spraying

The dosage required is $1.0-1.5$ liters hector which is to be diluted in 500-700 liters of water. We are selecting 1.5 liters to be diluted in 698.5 liters of water. Which makes the total volume to be sprayed equal to 700 liters/hector. The selected width for nozzle spacing is $25 \mathrm{~cm}$ and selected number of nozzles are 4 . These nozzles can be set over a boom width of $100 \mathrm{~cm}$. The desired speed is $16.5 \mathrm{~km} / \mathrm{h}$.

Required $1 / \mathrm{min}=\frac{700 \times 16.5 \times 25}{60000}=4.81 \mathrm{l} / \mathrm{min}$

The nozzle tip can be selected using the $1 / \mathrm{min}$ required using manufacturers guide.

Selected Nozzle tip: TeeJet air induction Turbo Twinjet AITTJ60-11015VP(<30psi(2bar))

Features: Rated excellent for systemic type herbicides which Also has an excellent drift management and PWM control. Recommended optimum spray height is $50 \mathrm{~cm}$ which is approximately equal to $0.5 \mathrm{~m}$.

The nozzle assembly include a cap, Adapter(outlet), orifice plate, strainer and body (inlet).(Appendix-1)

\section{KINEMATICS AND DYNAMICS OF MOTION}

\section{A. Figures and Tables}

Considering the drone as a body under kinematic motion the climb of the drone is considered to be $1.5 \mathrm{~m}$ for spraying and the climb rate is considered to be $0.15 \mathrm{~m} / \mathrm{s}$ i.e. the climb of $1.5 \mathrm{~m}$ will be achieved in 10 seconds. 


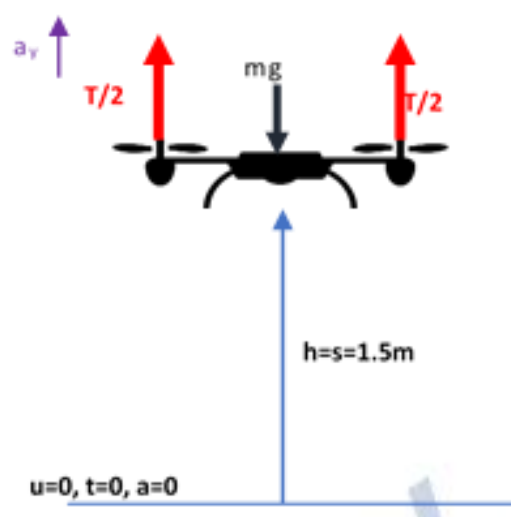

Fig 4. 1 Drone in Throttle motion

Considering the kinematic equation in vertical direction,

$$
\mathrm{s}=\mathrm{ut}+\frac{1}{2}\left(a_{y}-g\right) t^{2}
$$

For the initial condition $\mathrm{u}=0$ at $\mathrm{t}=0 \mathrm{~s}$ and ay be the acceleration at $\mathrm{t}=10 \mathrm{~s}$. For achieving the climb of $1.5 \mathrm{~m}$,

Acceleration,

$$
\begin{gathered}
a_{y}=\frac{S}{2 t^{2}}+g \\
a_{y}=9.84 \mathrm{~m} / \mathrm{s}^{2}
\end{gathered}
$$

Thrust required for the climb is given by,

$$
\mathrm{T}=\mathrm{m} a_{y}+\mathrm{mg}
$$

For the total mass, $m=14 \mathrm{~kg}$ the thrust value is,

$$
\begin{aligned}
& \mathrm{T}=257.1 \mathrm{~N} \\
& \mathrm{~T}=26.20 \mathrm{~kg}
\end{aligned}
$$

Thrust required per motor for 8 motors will be,

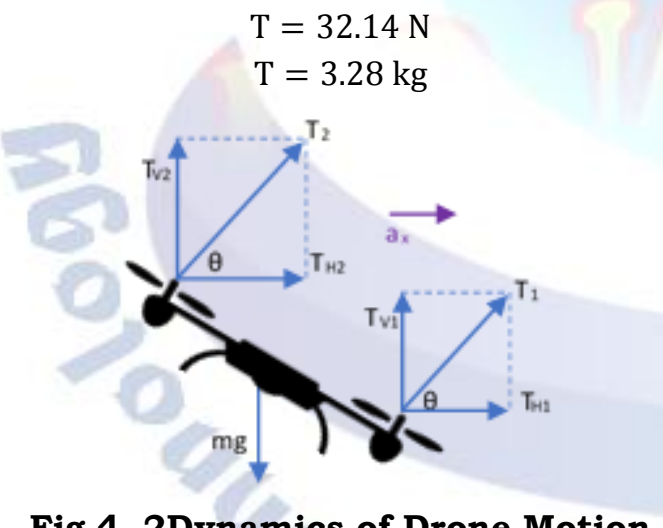

Fig 4. 2Dynamics of Drone Motion

Now, we are considering the pitch motion (forward motion) of the drone. It can be stated as per the mechanics of the motion that the front motors will generate less thrust as compared to the rear and also the sum of the vertical component of the thrust must be equal to the total thrust required to keep the drone afloat while the horizontal component will contribute in the forward movement.

Now, for achieving the speed of $6.33 \mathrm{~m} / \mathrm{s}$ in $6 \mathrm{~s}$, let us consider the acceleration $\mathrm{a}_{\mathrm{x}}=1.05 \mathrm{~m} / \mathrm{s}^{2}$. Also, $\mathrm{T}_{\mathrm{H} 1}=\mathrm{T}_{1} \sin \theta, \quad \mathrm{T}_{\mathrm{H} 2}=\mathrm{T}_{2} \sin \theta, \quad \mathrm{T}_{\mathrm{V} 1}=\mathrm{T}_{1} \cos \theta \quad$ and
$\mathrm{T}_{\mathrm{V} 2}=\mathrm{T}_{2} \cos \theta$. Therefore, the tilt can be calculated using

$$
\begin{gathered}
T_{H 1}+T_{H 2}=m a_{x}=14 \times 6.33=88.62 \mathrm{~N} \\
\left(T_{1}+T_{2}\right) \sin \theta=88.62 \mathrm{~N} \ldots(1)
\end{gathered}
$$

Similarly,

$$
\begin{gathered}
T_{V 1}+T_{V 2}=257.1 \mathrm{~N} \\
\left(T_{1}+T_{2}\right) \cos \theta=257.1 \mathrm{~N}
\end{gathered}
$$

Therefore, the tilt $\theta$ can be calculated as, eq(1)/eq(2)

$$
\begin{gathered}
\tan \theta=\frac{88.62}{257.1} \\
\theta=\tan ^{-1}\left(\frac{88.62}{257.1}\right) \\
\theta=19^{\circ}
\end{gathered}
$$

\section{TANK AND SPRAYING SYSTEM}

The spraying tank has a certain set of requirements, the prime requirements can be identified as capacity, less or no chemical affinity or reaction, strength to sustain the pressure variation and light weight. Most of these criteria are fulfilled by ABS. With low density as much as 1010 $\mathrm{kg} / \mathrm{m} 3$, the weight it will add to the drone assembly will be lesser compared to the other materials. The thickness of tank is $10 \mathrm{~mm}$, in order to sustain the fluid pressure as well as an accidental impact.

Table 6.1 Material Properties for Tank

\begin{tabular}{|l|l|l|l|}
\hline \multicolumn{4}{|c|}{ ABS (Acrylonitrile-Butadlene-Styrene) } \\
\hline $\begin{array}{l}\text { Density } \\
\left(\mathrm{Kg} / \mathrm{m}^{3}\right)\end{array}$ & $1010-1210$ & $\begin{array}{l}\text { Elongation } \\
\text { (\%strain) }\end{array}$ & $0.015-1$ \\
\hline $\begin{array}{l}\text { Yield } \\
\begin{array}{l}\text { Strength } \\
\text { (MPa) }\end{array}\end{array}$ & $18.5-51$ & $\begin{array}{l}\text { Fracture } \\
\text { Toughness } \\
\text { (MPa) }\end{array}$ & $1.19-4.29$ \\
\hline $\begin{array}{l}\text { Tensile } \\
\begin{array}{l}\text { Strength } \\
\text { (Mpa) }\end{array}\end{array}$ & $27-55.2$ & $\begin{array}{l}\text { Young's } \\
\text { Modulus } \\
\text { (GPa) }\end{array}$ & $1.19-2.9$ \\
\hline
\end{tabular}

A tank with 3 lt. capacity is designed in CATIA V5 keeping the width dimension as $100 \mathrm{~mm}$ while $30000 \mathrm{~mm}^{2}$ is kept as the perpendicular area while the angle of front face is varied between 0 to $60^{\circ}$ in the steps of $10^{\circ}$. The tank is connected to tubes and later connected to nozzle boom attached at the bottom of the drone. The pump is operated using an actuator mechanism for intermittent as well as continuous spraying operation.(Appendix-2)

\section{ANALYSIS OF TANK}

The created geometry is then analyzed in ANSYS 19.2 FLUENT CFD module. The tank is tilted at $19^{\circ}$ to simulate actual condition of forward pitch while in operation. After cleaning, meshing and setup a CFD simulation was conducted to find out $\mathrm{C}_{1} / \mathrm{C}_{\mathrm{d}}$ ratio to find out the optimum performing tank. Four counters were obtained to visualize the 
Table 7.1 Conditions of simulation

\begin{tabular}{|l|l|}
\hline $\begin{array}{l}\text { Flow inlet } \\
\text { (velocity-type) }\end{array}$ & Relative Velocity=6.33 m/s \\
\hline $\begin{array}{l}\text { Outlet } \\
\text { (pressure-type) }\end{array}$ & $\begin{array}{l}\text { Gauge pressure (pressure } \\
\text { over 101325 Pa) }=0 \mathrm{~Pa}\end{array}$ \\
\hline $\begin{array}{l}\text { Contact } \\
\text { boundary } \\
\text { (wall-type) }\end{array}$ & \multicolumn{1}{|c|}{ No slip stationary wall } \\
\hline $\begin{array}{l}\text { Flow Domain } \\
\text { (fluid-type) }\end{array}$ & $\begin{array}{l}\text { Density= } \\
\mathrm{kg} / \mathrm{m}^{3} ; \text { Viscosity=1.806 } \mathrm{x} \quad 10^{-5} \\
\mathrm{~kg} / \mathrm{m}^{-\mathrm{s}}\end{array}$ \\
\hline \multicolumn{1}{|c|}{ Model } & $\begin{array}{l}\text { Viscous Turbulent, Realizable } \\
\text { K-epsilon (2 eqs.) with Standard } \\
\text { wall Function model. }\end{array}$ \\
\hline Solution & $\begin{array}{l}\text { Double Precision; Second Order } \\
\text { Momentum Equation. }\end{array}$ \\
\hline
\end{tabular}
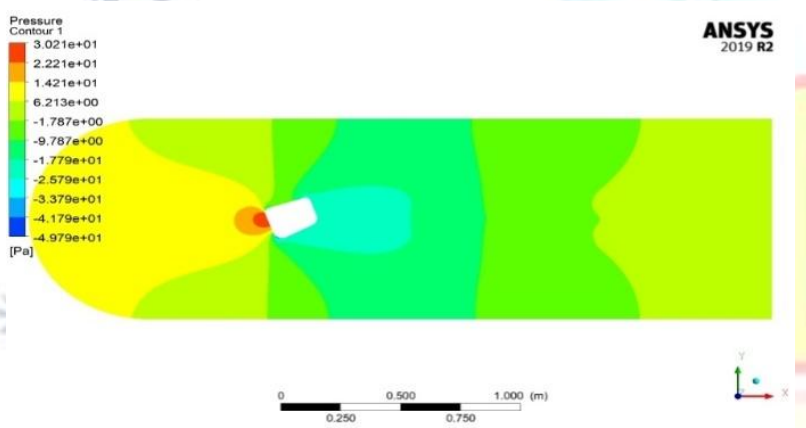

Fig 7. 1 Total pressure at $0^{\circ}$
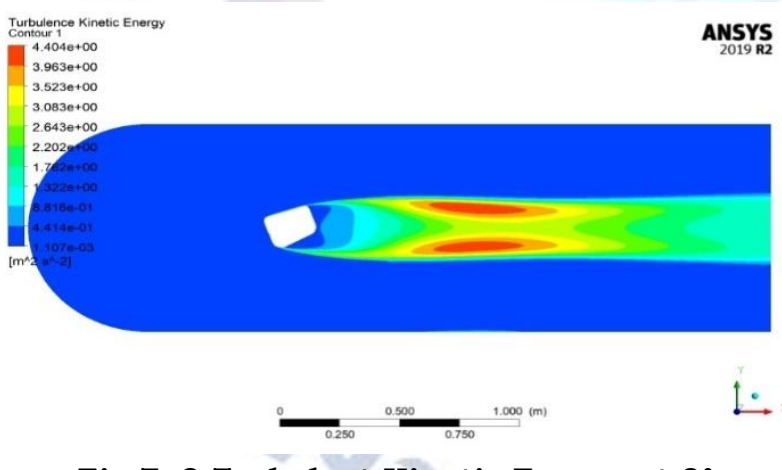

Fig 7. 2 Turbulent Kinetic Energy at $0^{\circ}$

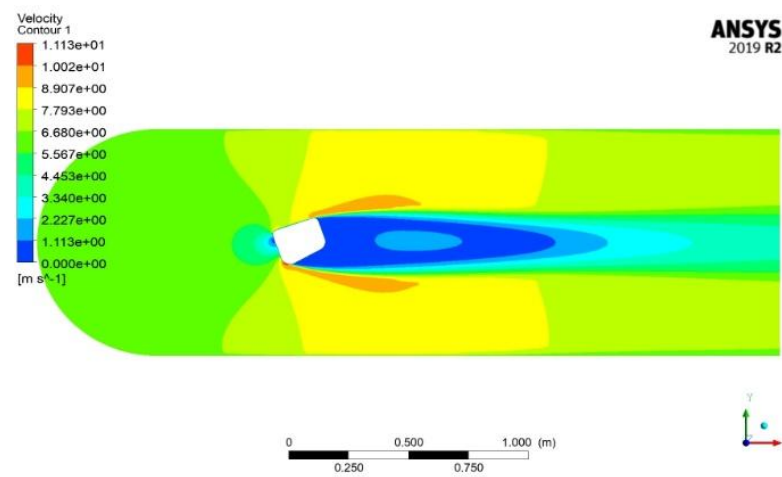

Fig 7. 3 Velocity Contour at $0^{\circ}$ performance namely; Total Pressure, Total Kinetic Energy, Velocity Contour and Wall Shear Stress. The table enlists the condition in the simulation environment where tank was kept steady and the air with relative velocity $6.33 \mathrm{~m} / \mathrm{s}$ $(22.8 \mathrm{kmph})(4.58 \mathrm{~m} / \mathrm{s}(16.5 \mathrm{kmph})+1.75 \mathrm{~m} / \mathrm{s}$ $(6.3 \mathrm{kmph}))$ i.e. the addition of two opposite velocities viz. drone velocity and velocity of air. The air properties at inlet and outlet were applied to fulfill the initial conditions of simulation. Drag and Lift Coefficient monitors were established to calculate the effect of both drag and lift force independent of the area of application. The solver carried out the solution process in order for iterations to converge at certain point and drag and lift coefficients were noted from the console.

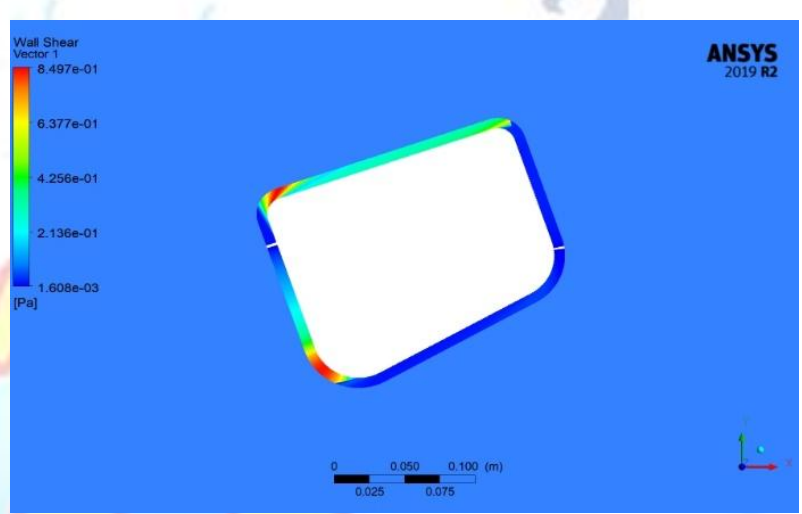

Fig 7. 4 Wall Shear Stress at $0^{\circ}$

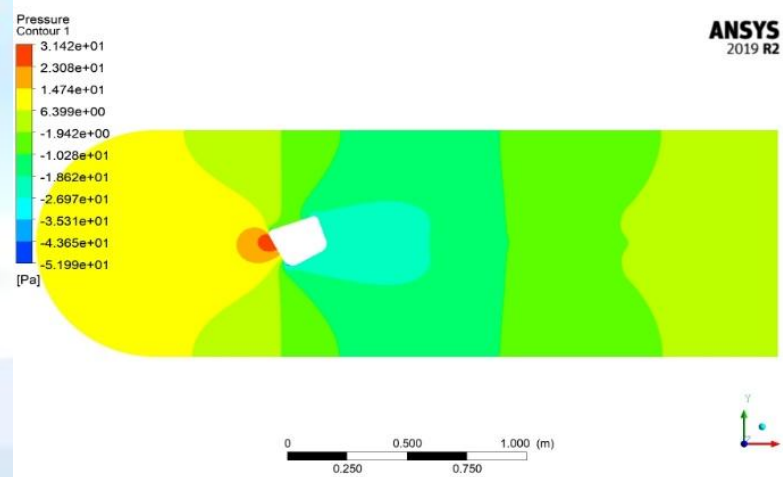

Fig 7. 5Total pressure at $10^{\circ}$

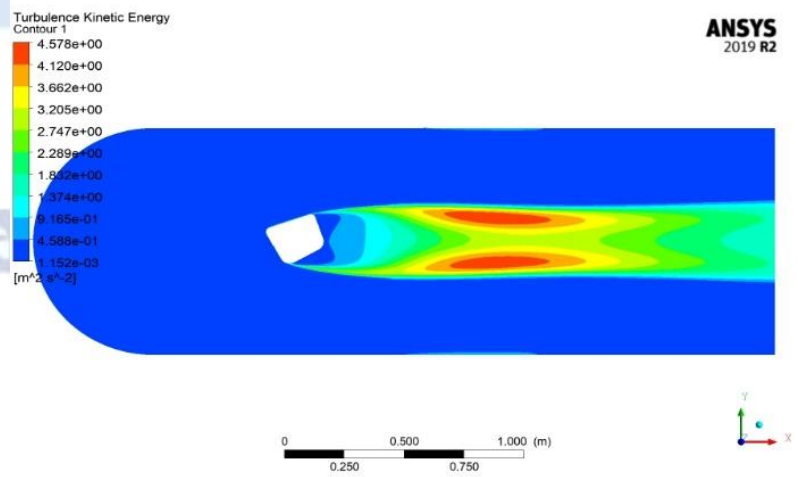

Fig 7. 6Turbulent Kinetic Energy at $10^{\circ}$ 

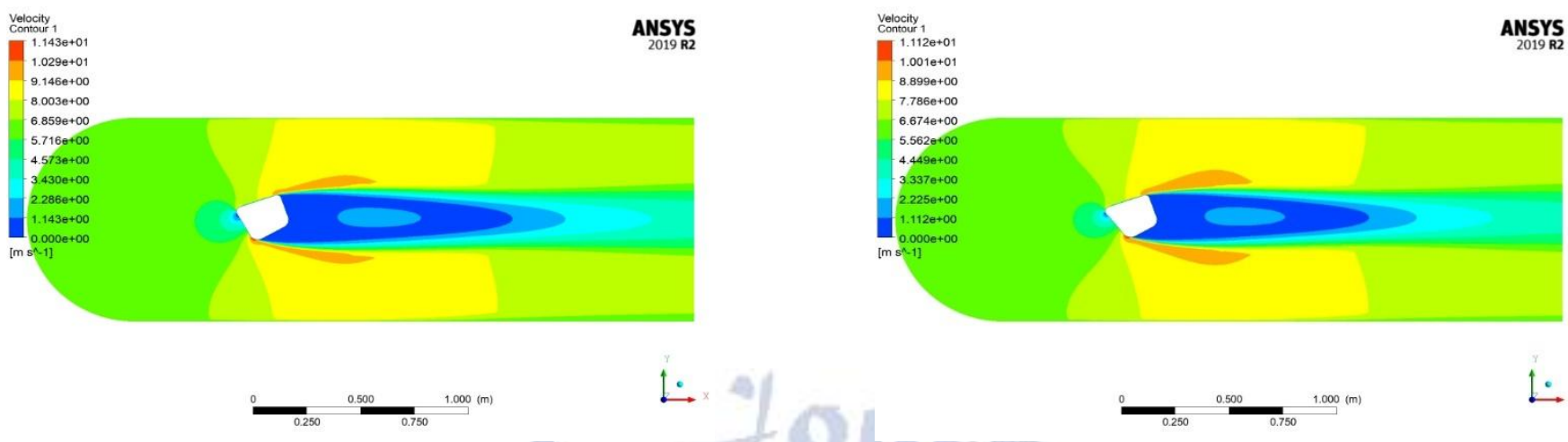

Fig 7. 7Velocity Contour at $10^{\circ}$

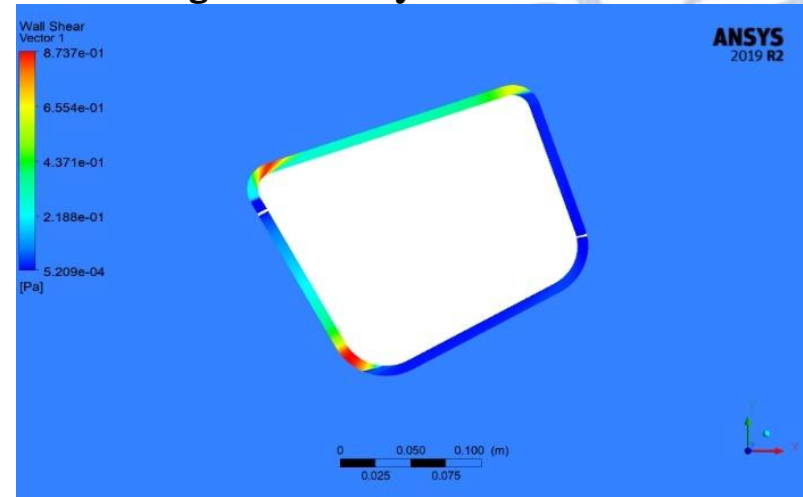

Fig 7. 8Wall Shear Stress at $10^{\circ}$

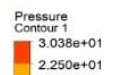

Pressure
Contour 1
Conse
$3.038 \mathrm{e}+01$
$2.250 \mathrm{e}+01$

$\underset{2019 \text { R2 }}{\text { ANSYSS }}$

$-6.746 \mathrm{e}+00$

$-1.132 e+00$
$-9.010 e+00$

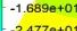

$-2.477 \mathrm{e}+01$
$-3.264 \mathrm{e}+01$

$-3.264 \mathrm{e}+0$,

${ }_{[\mathrm{Pa}]}^{-4.840 \mathrm{e}+01}$
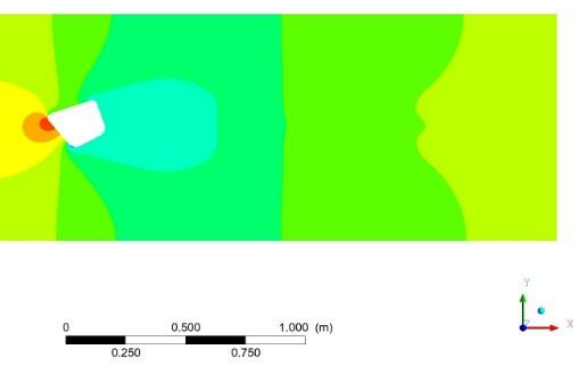

Fig 7. 9Total pressure at $20^{\circ}$

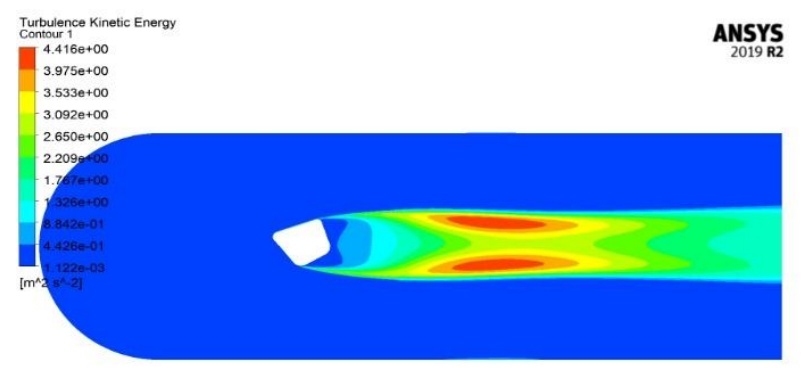

$\underset{2019 \text { R2 }}{\text { NSYS }}$

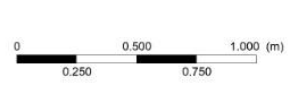

$\stackrel{\leftrightarrow}{\longrightarrow}$

Fig 7. 10Turbulent Kinetic Energy at $20^{\circ}$

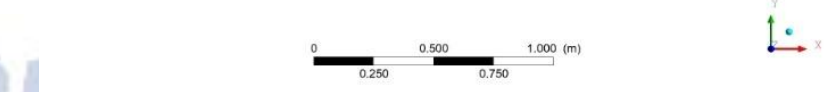

Fig 7. 11 Velocity Contour at $20^{\circ}$

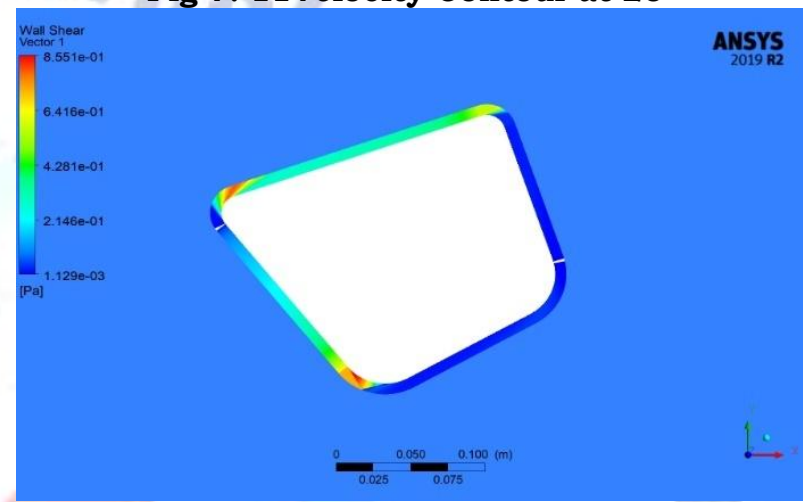

Fig 7. 12Wall Shear Stress at $20^{\circ}$

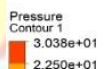

$3.038 \mathrm{e}+01$
$2.250 \mathrm{e}+01$
$-1.462 \mathrm{e}+01$

$-1.462 e+01$
$-6.747+00$
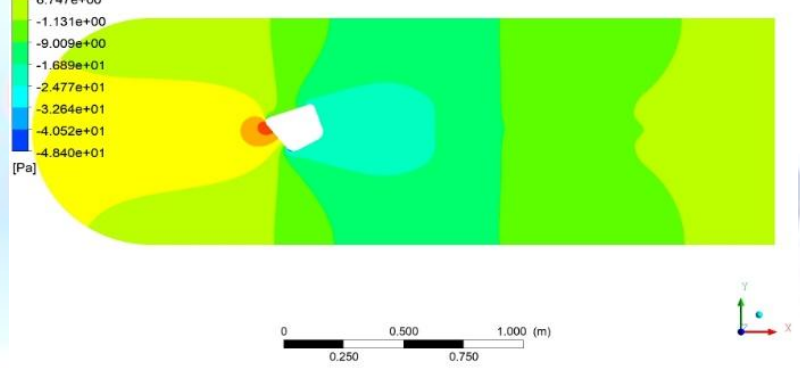

Fig 7. 13Total pressure at $30^{\circ}$

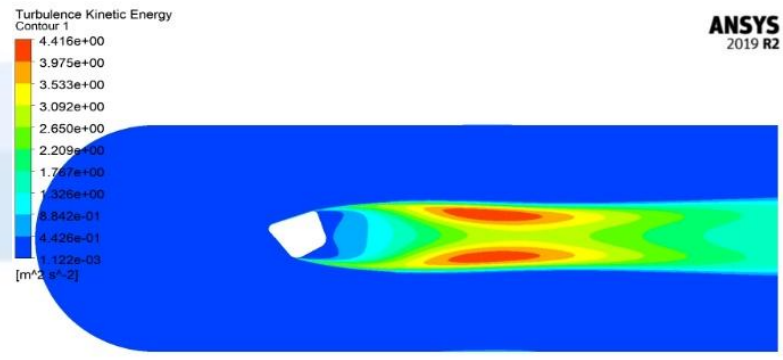

$\underbrace{0.5000}_{0.250} \underbrace{1.000}_{0.750}(\mathrm{~m})$

$\stackrel{1 \cdot}{\longrightarrow}$

Fig 7. 14Turbulent Kinetic Energy at $30^{\circ}$ 

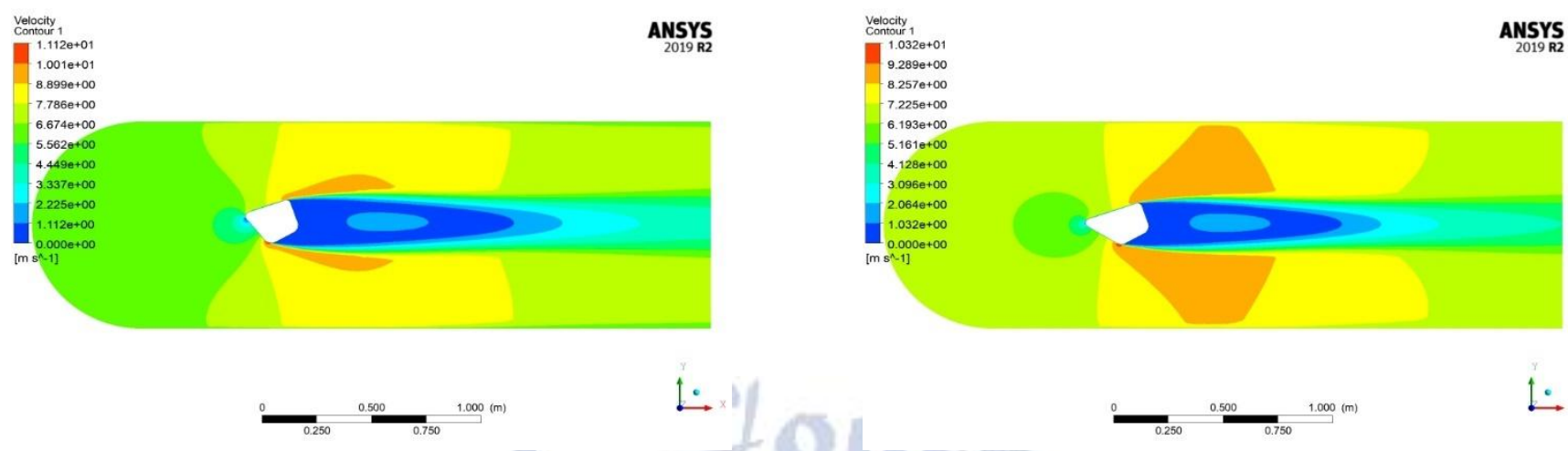

$\stackrel{\circ}{\longrightarrow}$

Fig 7. 15Velocity Contour at $30^{\circ}$

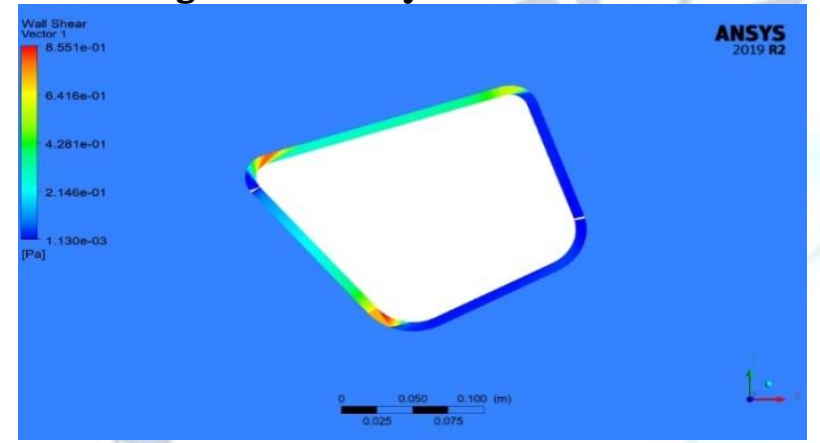

Fig 7. 16Wall Shear Stress at $30^{\circ}$

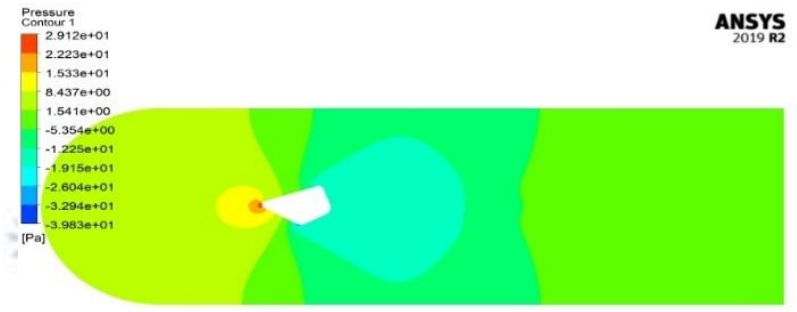

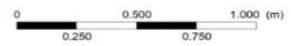

Fig 7. 17 Total pressure at $40^{\circ}$

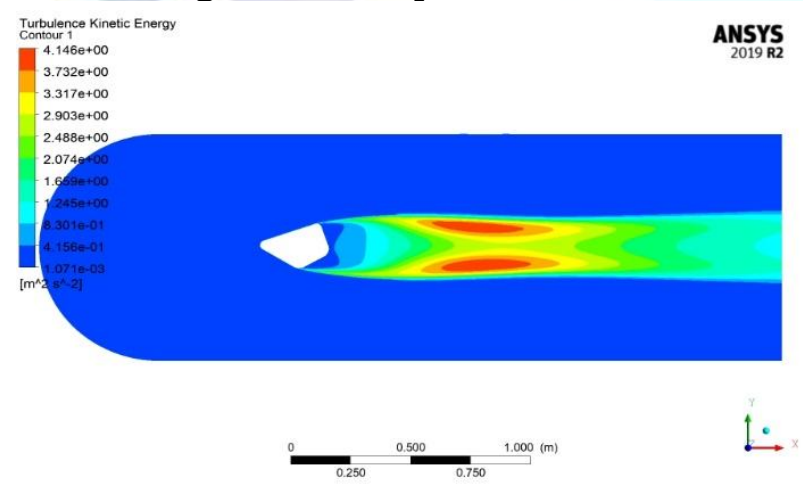

Fig 7. 18'Turbulent Kinetic Energy at $40^{\circ}$
Fig 7. 19Velocity Contour at $40^{\circ}$

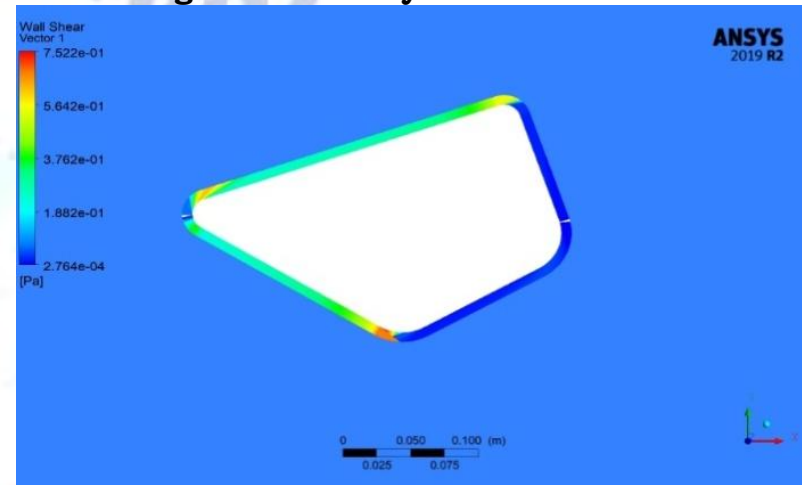

Fig 7. 20Wall Shear Stress at $40^{\circ}$

ANSYS

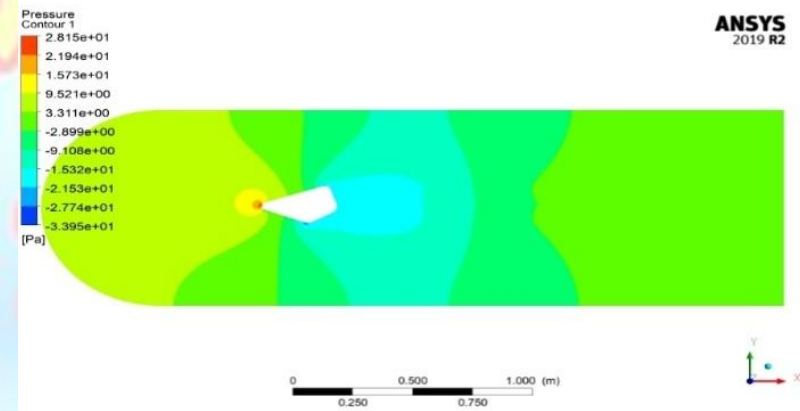

Fig 7. 21Total pressure at $50^{\circ}$
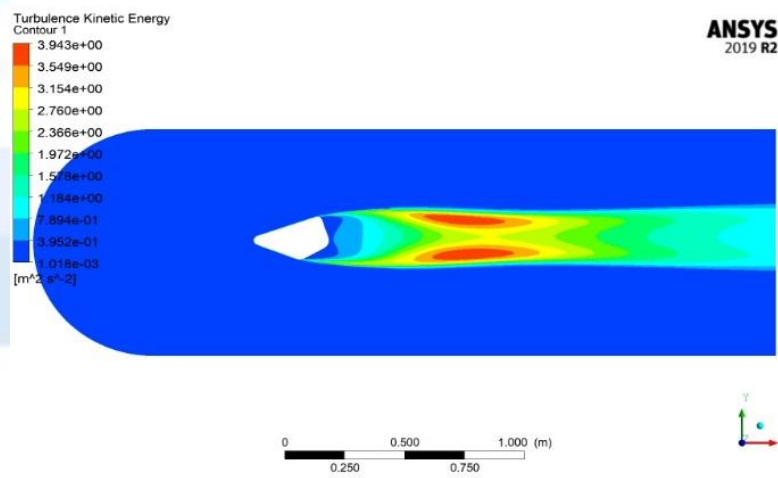

$\stackrel{\leftrightarrow}{\longrightarrow}$

Fig 7. 22 Turbulent Kinetic Energy at $50^{\circ}$ 

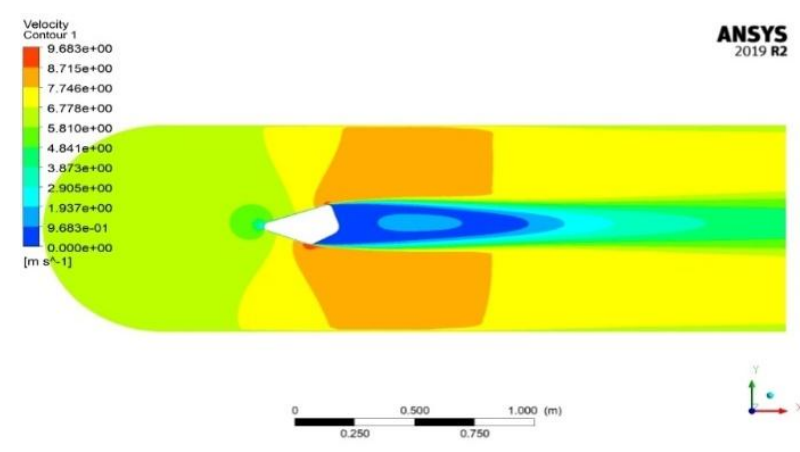

$\stackrel{-}{\circ}$

Fig 7. 23Velocity Contour at $50^{\circ}$

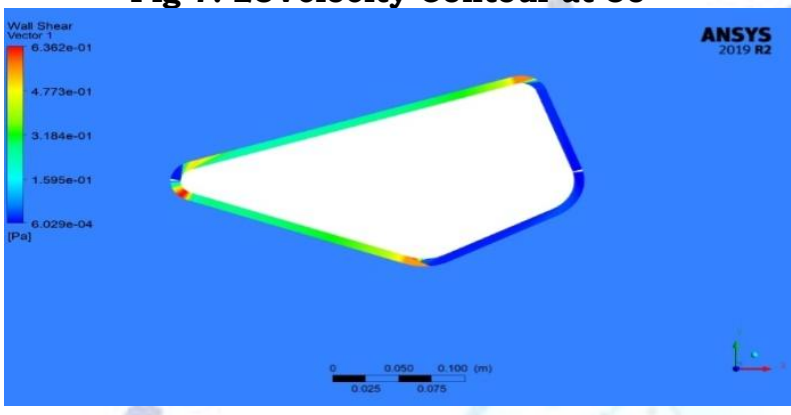

Fig 7. 24Wall Shear Stress at $5^{\circ}$

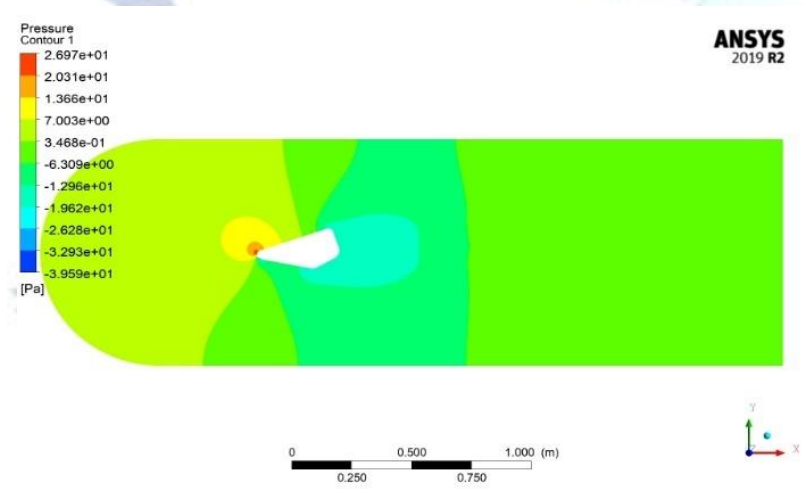

Fig 7. 25Total pressure at $60^{\circ}$

The results obtained after conducting the simulation are listed in the table below:

Table 7.2 Tank front face angle vs $C_{1} / C_{d}$

\begin{tabular}{|c|c|c|c|}
\hline $\begin{array}{l}\text { Tank } \\
\text { front } \\
\text { face } \\
\text { angle } \\
\text { (a) }\end{array}$ & $\begin{array}{c}\text { Drag } \\
\text { Coefficient }\end{array}$ & $\begin{array}{c}\text { Lift } \\
\text { Coefficient }\end{array}$ & $\mathrm{C}_{\mathrm{L}} / \mathrm{C}_{\mathrm{D}}$ \\
\hline 0 & $1.9466 \mathrm{e}-01$ & $2.4253 \mathrm{e}-02$ & $1.2459 \mathrm{E}-01$ \\
\hline 10 & $2.1286 \mathrm{e}-01$ & $3.8950 \mathrm{e}-02$ & $1.8298 \mathrm{E}-01$ \\
\hline 20 & $1.7884 \mathrm{e}-01$ & $3.3568 \mathrm{e}-02$ & $1.8769 \mathrm{E}-01$ \\
\hline 30 & $1.7590 \mathrm{e}-01$ & $5.1481 \mathrm{e}-03$ & $2.9267 \mathrm{E}-02$ \\
\hline 40 & $1.4956 \mathrm{e}-01$ & $-1.5184 \mathrm{e}-02$ & $-1.0152 \mathrm{E}-01$ \\
\hline 50 & $1.2938 \mathrm{e}-01$ & $-7.9099 \mathrm{e}-02$ & $-6.1136 \mathrm{E}-01$ \\
\hline 60 & $1.0522 \mathrm{e}-01$ & $-9.5522 \mathrm{e}-02$ & $-8.6279 \mathrm{E}-01$ \\
\hline
\end{tabular}
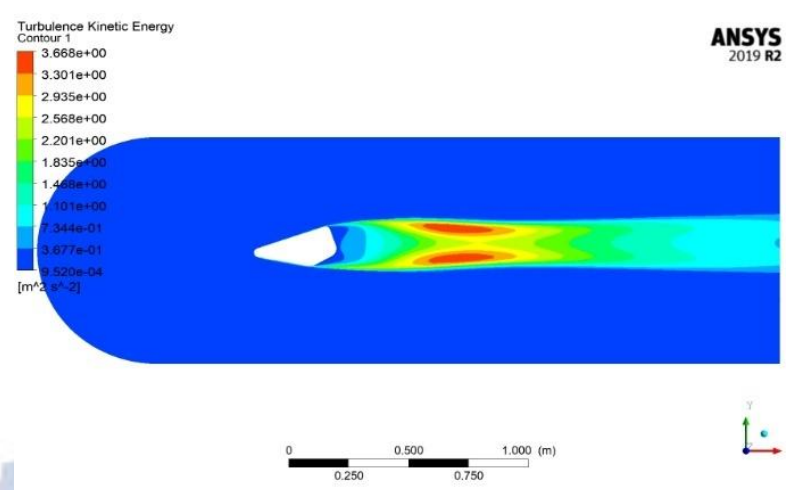

$\stackrel{\dagger}{\longrightarrow}$

Fig 7. 26Turbulent Kinetic Energy at $60^{\circ}$
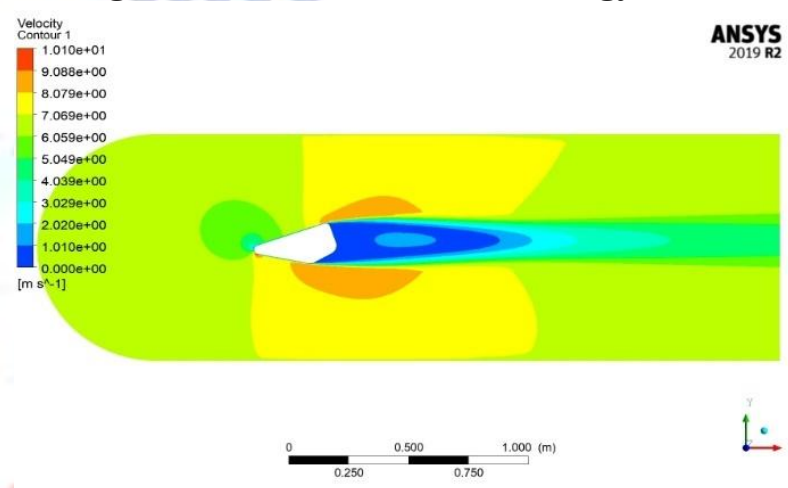

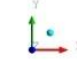

Fig 7. 27 Velocity Contour at $60^{\circ}$

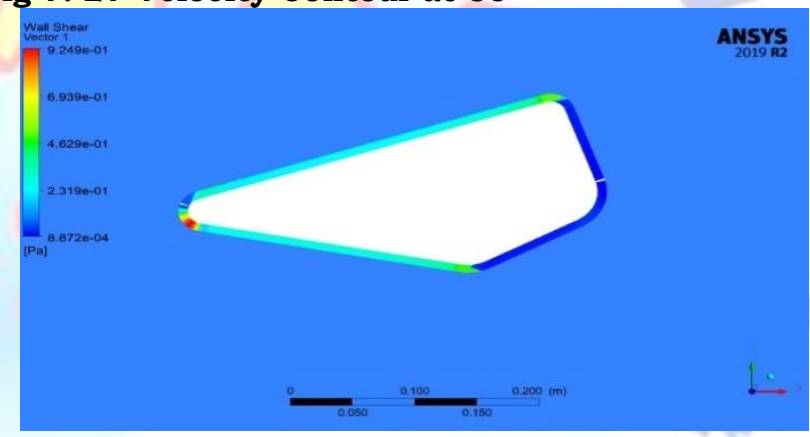

Fig 7. 28Wall Shear Stress at $60^{\circ}$

( $\alpha$ ) vs $C_{L}, C_{D} \& C_{L} / C_{D}$

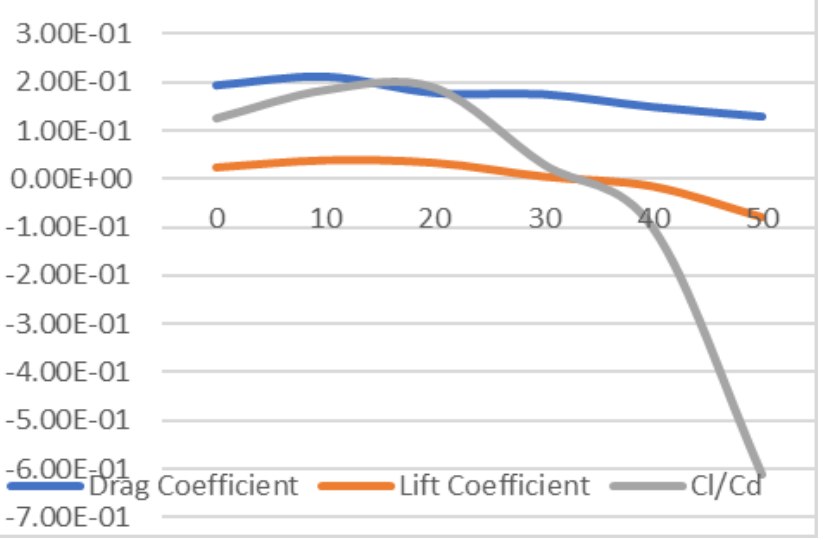

Fig 7. 29 Plot ofa vs $C_{L}, C_{D}$ and $C_{L} / C_{D}$

Observing the plot and Table it can be seen that there is steep decrease in lift to drag coefficient ratio which indicates that $20^{\circ}$ is the most suitable face tilt that should be chosen for the tank. Also, it 
can be seen from the contours that the drag due to formation wake increases with increase in the face tilt resulting in the formation of low pressure zone and adding to the overall drag it results into a resultant increase.

\section{CONTROL MATRIX OF SPRAYING DRONE}

When the fluid is in the static condition the pressure variation can only be observed in the vertical direction but when the fluid is in motion (rigid), it generates a difference of pressure between the front surface and the rear surface.
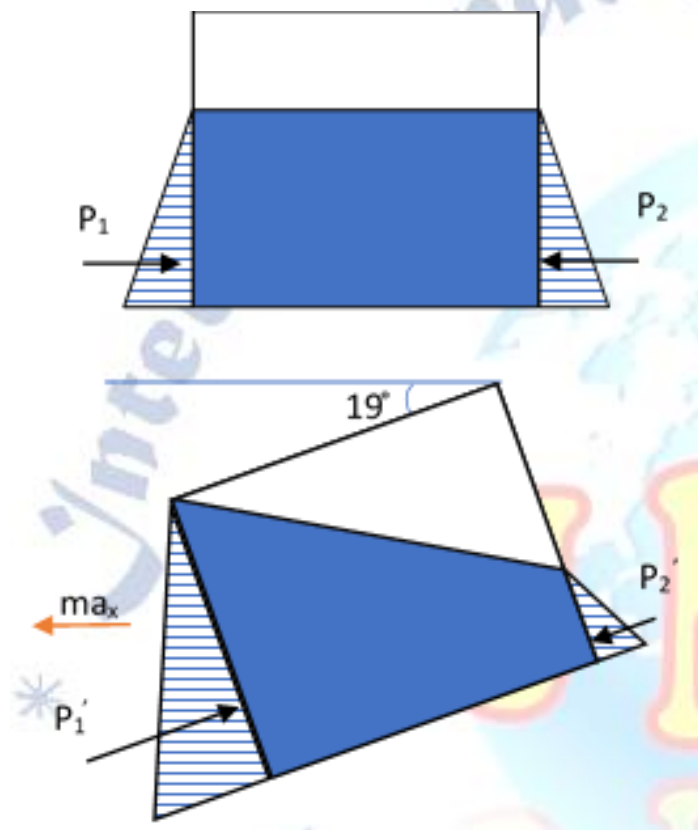

Fig 8. 1 Variation of pressure force in the tank The fig shows the variation of pressure of after the tilt due to the pitch motion. The fluid in static condition acts normal to the surface. The hydrostatic force on such surfaces is given by

$$
\mathrm{P}=\rho g \mathrm{Ah}
$$

Where, P- Hydrostatic Force, $\rho$-density of the fluid A- Area of the surface $h$ - vertical distance of $C G$ from the free surface of liquid.

As it can be seen by the illustration ' $h$ ' changes with the rotation of the container. The difference between $\mathrm{P}_{1}$ and $\mathrm{P}_{2}$ (shown as the reaction forces in the figure) gives rise to a disturbing force which should be considered when considering the control matrices. The force matrix $\mathrm{P}$ can be given by,

$$
[P]=\left[\begin{array}{c}
P_{1 x}-P_{2 x} \\
P_{1 y}-P_{2 y} \\
\rho g A h
\end{array}\right]
$$

When the drone is rotated for the pitch or roll motion. The rotational matrix with respect to an inertial frame is given by,
$[R]$ $=\left[\begin{array}{ccc}\cos \phi \cos \psi-\cos \theta \sin \phi \sin \psi & \cos \psi \sin \phi-\cos \phi \cos \theta \sin \psi & \sin \theta \sin \psi \\ \cos \theta \cos \psi \sin \phi-\cos \phi \sin \psi & \cos \phi \cos \theta \cos \psi-\sin \phi \sin \psi & -\cos \psi \sin \theta \\ \sin \phi \sin \theta & \cos \phi \sin \theta & \cos \theta\end{array}\right]$ Now, the modified equation of motion of the drone can be given by[28]

$$
m \ddot{x}=\left[\begin{array}{c}
0 \\
0 \\
m g
\end{array}\right]+R\left[\begin{array}{c}
\tau_{\text {roll }} \\
\tau_{\text {pitch }} \\
\tau_{\text {yaw }}
\end{array}\right]+F_{D}+R P
$$

\section{Conclusion}

The following conclusions can be drawn as a result of designing the spraying system for drone:

1. Selection of spraying liquid is a critical step and these liquids shall be used in the critical sections were crops are affected resulting into an economic and environmental friendly spraying operation.

2. The drag to lift ratio efficiency decreases beyond $20^{\circ}$ front face angle including the $19^{\circ}$ tilt for the pitch motion. Hence the drone tank shall be operated and designed below the mentioned specification.

3. The Hydrostatic pressure plays a vital role while obtaining the control equation for drone and hence a controller shall be designed in such a way that it will compensate for disturbance due to hydrostatic pressure. 
APPENDIX

\section{Teejet AI Turbo TwinJet AITTJ60-11015}

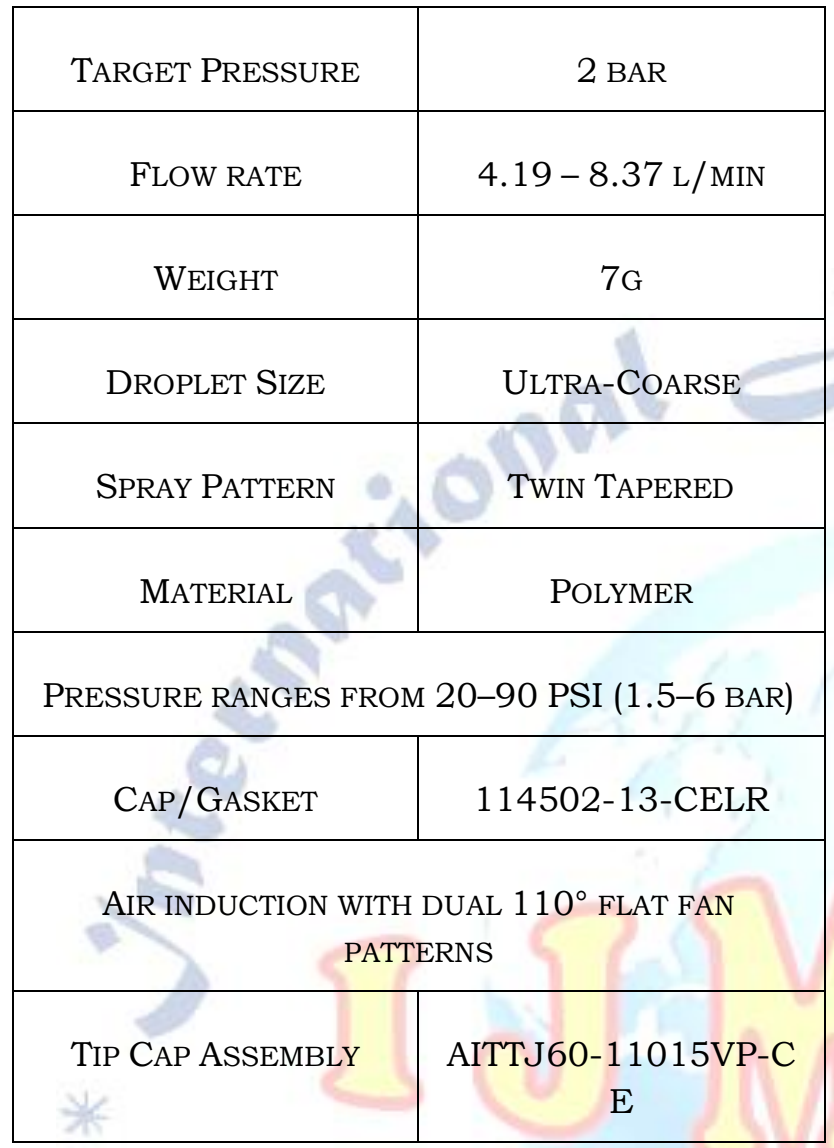

\section{SEAFLO 21 SERIES DC Diaphragm Pump $12 \mathrm{~V} / 24 \mathrm{~V}$ 2.0-4.3LPM 17-80PSI}

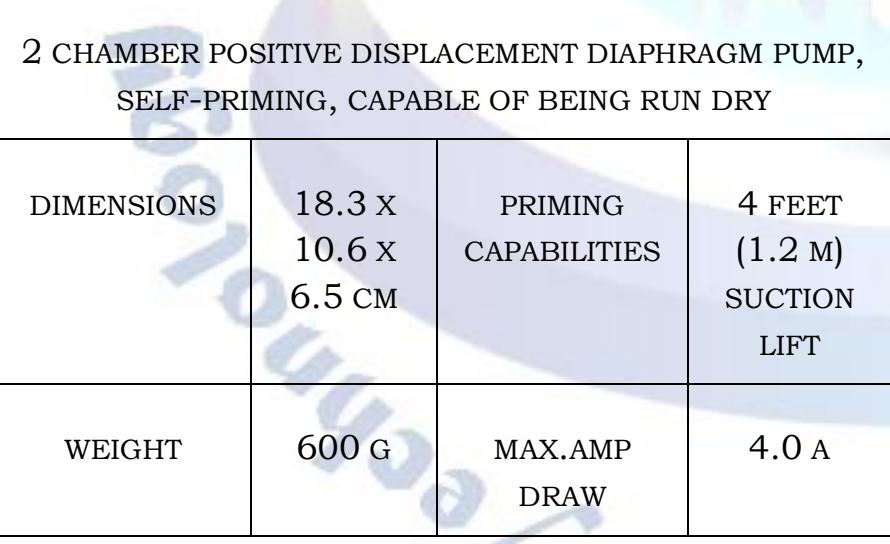

REFERENCES

[1] Wen, S., Han, J., Ning, Z., Lan, Y., Yin, X., Zhang, J., \& Ge, Y. (2019). Numerical analysis and validation of spray distributions disturbed by quad-rotor drone wake at different flight speeds. Computers and Electronics in Agriculture, 166 , 105036. doi:10.1016/j.compag.2019.105036

[2] Yallappa, D., Veerangouda, M., Maski, D., Palled, V., \& Bheemanna, M. (2017). Development and evaluation of drone mounted sprayer for pesticide applications to crops. 2017 IEEE Global Humanitarian Technology Conference (GHTC). doi:10.1109/ghtc.2017.8239330
[3] Meivel, S., Maguteeswarn, R., Gandhiraj, N., Srinivasan, G. (2016) "Quad copter UAV based Fertilizer and Pesticide Spraying System." International Academic Research Journal of Engineering Sciences, Vol 1 issue 1, February 2016, Page No.8-12.

[4] Y. Huang, W. C. Hoffmann, Y. Lan, W. Wu, \& B. K. Fritz. (2009). Development of a Spray System for an Unmanned Aerial Vehicle Platform. Applied Engineering in Agriculture, 25(6), 803-809. doi:10.13031/2013.29229

[5] Vihari, M. M., Nelakuditi, U. R., \& Teja, M. P. (2018). IoT based Unmanned Aerial Vehicle system for Agriculture applications. 2018 International Conference on Smart Systems and Inventive Technology (ICSSIT). doi:10.1109/icssit.2018.8748794

[6] Karan Kumar Shaw , Vimalkumar R. "Design and Development of a Drone for Spraying Pesticides, Fertilizers and Disinfectants" International Journal of Engineering Research \& Technology (IJERT) Vol. 9 Issue 05, May-2020

[7] Xuan Li et al, "Best Management Practices for Unmanned Aerial Vehicles (UAVs) Application of Insecticide Products on Rice and Other Field Crops" An ASABE Meeting Presentation DOI: Paper Number: 1901493 https://doi.org/10.13031/aim.201901493

[8] Aleksandra Pachuta et al," Evaluation of liquid transverse distribution under a twin spray jet installed on a drone " Mendel Net 7-8 November 2018.

[9] Boguslawa Berner et al," Estimation of liquid deposition on corn plants sprayed from a drone "Mendel Net 7-8 November 2018

[10] Anken Thomas et al," Working Quality, Drift Potential and Homologation of Spraying Drones in Switzerland" M. Gandorfer et al.: Digitalisierung für Mensch, Umwelt und Tier, Lecture Notes in Informatics (LNI), Gesellschaft für Informatik, Bonn 2020

[11] Yayong Chen et al ," An effective spray drift-reducing method for a plant-protection unmanned aerial vehicle" International journal of agricultural and biological engineering Vol 12 No 5 September 2019 10.25165/j.ijabe.20191205.4289

[12] Weicai Qin et al "Droplet deposition and efficiency of fungicides sprayed with small UAV against wheat powdery mildew" Int J Agric \& Biol Eng, Vol. 11 No.2 pg. 27

[13] S.Meivel M.E. et al," Quadcopter UAV Based Fertilizer and Pesticide Spraying System” International Academic Research Journal of Engineering Sciences Vol. no.1 issue no 1, February 2016, Page No.8-12

[14] Matsuura, F., Fukumi, J., \& Fukuda, K. (2017). Research of crop-sprayer for dotted farmland using airflow induced by UAV. 2017 56th Annual Conference of the Society of Instrument and Control Engineers of Japan (SICE). doi:10.23919/sice.2017.8105593

[15] Tejas S. Kabra et al ," Design, Development \& Optimization of a Quad-Copter for Agricultural Applications" International Research Journal of Engineering and Technology (IRJET) Volume: 04 Issue: 07 | July -2017

[16] Tang, Y., Hou, C. J., Luo, S. M., Lin, J. T., Yang, Z., \& Huang, W. F. (2018). Effects of operation height and tree shape on droplet deposition in citrus trees using an unmanned aerial vehicle. Computers and Electronics in Agriculture, 148, 1-7. doi:10.1016/j.compag.2018.02.026

[17] Qin, W., Xue, X., Zhang, S., Gu, W., \& Wang, B. (2018). Droplet deposition and efficiency of fungicides sprayed with small UAV against wheat powdery mildew. International Journal of Agricultural and Biological Engineering, 11(2), 27-32.

[18] Joseph E. Hunter et al ( April 2020), "Coverage and drift potential associated with nozzle and speed selection for 
herbicide applications using an unmanned aerial sprayer" , WSSA Volume 34, Issue 2 DOI: https://doi.org/10.1017/wet.2019.101

[19] Saddam Hussain et al (2019), "Spray Uniformity Testing of Unmanned Aerial Spraying System for Precise Argo-Chemical Applications" Pak. J. Agri. Sci., Vol. 56(4), 2019. DOI:10.21162/PAKJAS/ 19.8594

[20] https://www.weatheronline.in/weather/maps/city?FMM= $1 \& \mathrm{FYY}=2014 \& \mathrm{LMM}=12 \& \mathrm{LYY}=2019 \& \mathrm{WMO}=42867 \& \mathrm{CONT}$ $=$ inin $\&$ REGION $=0024 \&$ LAND $=I I \& A R T=W S T \& R=0 \& N O R E G$ ION=0\&LEVEL $=1628 \mathrm{LANG}=$ in\&MOD $=$ tab

[21] Department for Environmental Food and Rural Affairs UK, "Pesticides- Best Practice Guides" April 2005

[22] Partha P. Choudhury et al "Herbicide Use in Indian Agriculture" ICAR-Directorate of Weed Research, Jabalpur page $62-632016$

[23] Dibyendu Mondal et al "Eco-efficacy of pretilachlor 50\% EC in transplanted winter rice and itsresidual effect on lentil" Indian Journal of Weed Science 51(3): 220-226, 2019

[24] M. D. Survase et al, "Influence of mechanical and chemical weed management practices on growth and yield of transplanted rice" Journal of Crop and Weed, 9(2):190-192(2013)

[25] Government of India, Ministry of Agriculture \& Farmers Welfare Department of Agriculture, Cooperation \& Farmers Welfare Directorate of Plant Protection, Quarantine \& Storage Central Insecticides Board \& Registration Committee N.H. IV, Faridabad-121 001 "Major Uses of Pesticides Registered under the Insecticides Act, 1968 up to 31.05.2018 - HERBICIDES" page 29

[26] Meiqiao Lv et al "Influence of UAV flight speed on droplet deposition characteristics with the application of infrared thermal imaging" Int J Agric \& Biol Eng Vol. 12 No.3 10 May, 2019.

[27] A. S. Mat Su et al "Evaluation of the Spraying Dispersion and Uniformity Using Drone in Rice Field Application" 2018 MSAE Conference, Serdang, Selangor D. E., Malaysia. $7 \& 8$ February 2018

[28] M. Eatemadi "Mathematical Dynamics, Kinematics Modelling and PID Equation Controller of Quadcopter", International Journal of Applied Operational Research Vol. 7, No.1, pp 77-85, Winter 2017

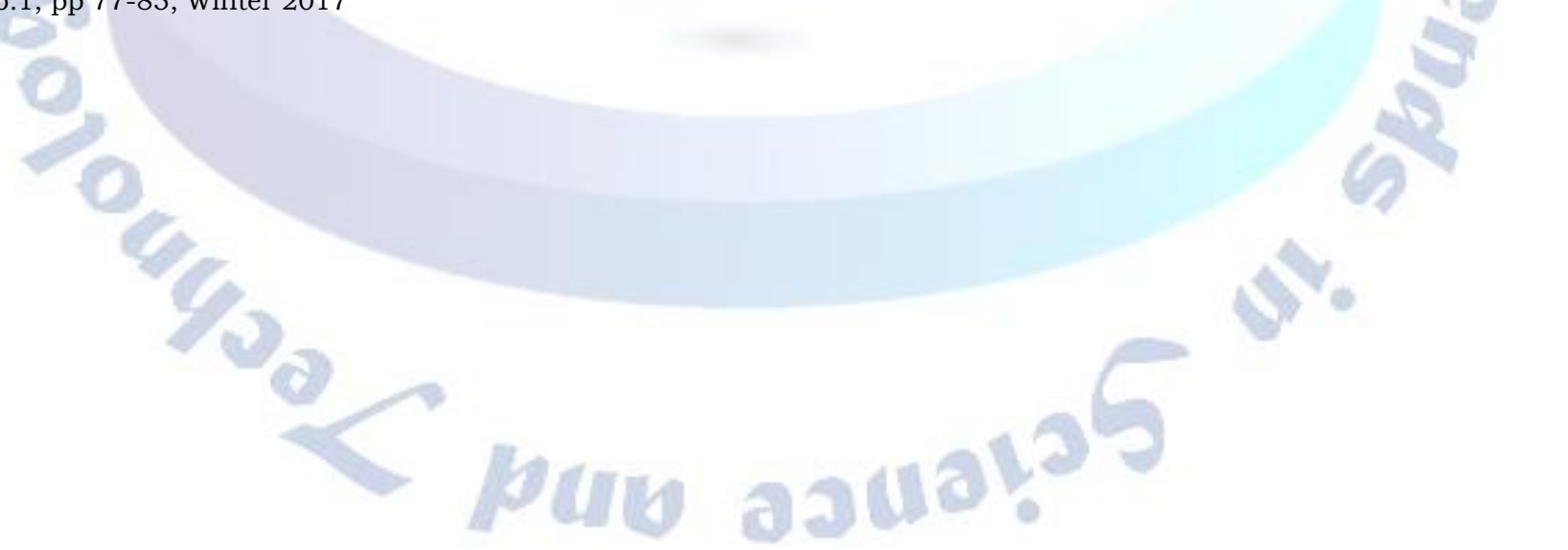

